\title{
Potensi Ekowisata Kelompok Sadar Wisata Pantai Mutiara Baru Desa Karya Makmur
}

\author{
Roby Rakhmadi ${ }^{\star}$, Arif Darmawan, Hadi Prayitno \\ Hubungan Internasional, Universitas Lampung, Bandar Lampung, 35145, Lampung, Indonesia
}

\begin{abstract}
Abstrak.
Adanya potensi ekowisata di kabupaten Lampung Timur perlu disikapi dengan pelatihan terhadap masyarakat di kawasan sekitarnya agar mampu melakukan pemanfaatan terhadap potensi tersebut. Desa Karya Makmur memiliki kelompok sadar wisata di pantai Mutiara Baru yang mampu melakukan pemberdayaan terhadap potensi tersebut. Pemberdayaan dalam kegiatan pengabdian ini dilakukan dengan metode ceramah dan demonstrasi. Selain melakukan pelatihan terhadap kegiatan ecotourism juga dilakukan pengelolaan sampah dalam pembuatan ecobrick agar nantinya alam tetap lestari. Untuk menjadi ekowisata hijau, kawasan pariwisata harus memiliki komitmen menerapkan pengelolaan sampah dengan mengoptimalkan daur ulang dan meminimalisasi penimbunan Sampah. Sampah dapat dimanfaatkan menajadi ekobrick untuk keindahan arsitektur kawasan pariwisata.
\end{abstract}

Kata kunci.

ekowisata, Desa Karya Makmur, ecobrick.

\section{PENDAHULUAN}

Pengelolaan limbah sangat menantang bagi negara berkembang karena tingginya biaya infrastruktur per-kapita dan basis sumber daya yang sedikit. Kurangnya kerangka perencanaan terpadu dalam karakteristik ini telah menghambat kemajuan pengelolaan limbah berkelanjutan. Pentingnya strategi pencegahan limbah dan penggunaan kembali sampah yang melibatkan masyarakat perlu dilakukan. Identifikasi dan evaluasi berbasis strategi pengelolaan limbah didasarkan pada proses partisipatif dapat berkontribusi pada tercapainya Tujuan Pembangunan Berkelanjutan [1]. Pengelolaan sampah banyak sekali alternatifnya, salah satunya menjadi energi. Investasi dan peningkatan teknologi WTE akan mendukung dorongan global untuk mencapai SDGs tujuh dan sebelas [2]. Sampah juga dapat dikelola menjadi material bangunan melalui teknologi ekobrik [3]. Untuk memulai membangun kesadaran pengelolaan sampah dengan prinsip 7R perlu didampingi kelompok masyarakat yang memiliki kemauan yang kuat untuk cerdas mengelola sampah. Kelompok masyarakat di sekitar pantai Mutiara Baru memiliki keinginan yang kuat untuk dapat membangun wilayahnya dengan penuh inovasi sekaligus hijau. Masyarakat ingin membangun kawasan green ecotourism dengan antusias. Saat ini sudah terjadi kolaborasi

\section{* Corresponding author: roby.rakhmadi007@fisip.unila.ac.id}

Received 18 November 2020; Received in revised form 28 November 2020; Accepted 9 December 2020 Available online 24 December 2020

Lembaga Penelitian dan Pengabdian Kepada Masyarakat

Universitas Lampung 
dengan kelompok penggiat lingkungan untuk mengambil sampah di lokasi pariwisata serta mewujudkan kesadaran wisata di desa tersebut.

Mitra belum mampu mengoptimalkan pengelolaan sampah yang ada di lokasi Pantai Mutiara Baru dan sekitarnya. Saat ini mitra masih bekerjsama dengan pihak lain dalam pengelolaan sampah. Sampah sampah yang dapat dimanfaatkan kembali belum mampu dikelola kembali missal dijadikan kompos, ekobrik atau pemanfaatn yang lain. Selain itu pengelolaan sektor pariwisata masih dilakukan secara tradisional dan masih perlu dilakukan pendampingan agar mampu mencapai tahap keberlanjutan baik secara ekologi maupun ekonomis. Dari hal di atas, maka permasalahan yang diajukan dalam pengabdian ini adalah bagaimana cara meningkatkan kesadaran wisata warga selaku pengelola Pantai Mutiara Baru Desa Karya Makmur di Labuhan Maringgai, Lampung Timur?

Adapun alasan dipilihnya warga generasi muda Desa Karya Makmur adalah karena desa ini memiliki kelompok karang taruna yang cukup peduli dengan kelestarian lingkungan. Selain itu, pantai Mutiara Baru yang berada di desa ini memiliki potensi pariwisata yang cukup besar dengan tambak dan pasir yang cukup bersih.

\section{METODE}

Untuk memecahkan permasalahan dalam kegiatan pengabdian kepada masyarakat ini, metode pelaksanaan yang akan digunakan meliputi: (1) memberikan pelatihan dan workshop dengan menyajikan materi melalui tatap muka langsung mengenai pengolahan dan pemilihan sampah dengan prinsip 7R; dan (2) melakukan simulasi dan pendampingan pembuatan ecobrick, hidroponik dan vertikultur. Sehingga, untuk melihat peningkatan yang terjadi selama pengabdian maka dilakukan pengisian quisioner, diantaranya: (1) Pre-Test, meninjau pengetahuan dan pemahaman anggota koperasi tentang pengolahan dan pemilihan sampah dengan prinsip 7R. (2) Observasi, dilakukan pada saat pelatihan berlangsung untuk mengetahui kesulitan/kendala yang dihadapai anggota koperasi; (3) Post-Test, memperlihatkan grafik keberhasilan dari pendampingan yang dilakukan kepada anggota koperasi.

\section{HASIL DAN PEMBAHASAN}

Penyuluhan berlangsung pada hari Rabu, tanggal 12 Agustus 2020 di Aula Pantai Mutiara Baru, Desa Karya Makmur, Labuhan Maringgai, Kabupaten Lampung Timur. Penyuluhan dihadiri oleh dosen FISIP Unila selaku nara sumber yang sedang mengabdi Roby Rakhmadi, S.Sos., M. Si., dosen FT Unila Hadi Prayitno, M.T., dosen FEB Unila Arif Darmawan, M.A. serta beberapa orang mahasiswa. Acara dibuka secara resmi oleh Kepala Desa Karya Makmur Bapak Nanang Wahono dan dimoderatori oleh Ketua Pokdarwis Supardiono. Peserta keseluruhan berjumlah 20 orang, berasal dari kalangan generasi muda Desa Karya Makmur, terutama pengurus dan anggota Karang Taruna.

Dalam proses pelatihan Roby Rakhmadi, M. Si. menyampaikan materi tentang Pariwisata Berkelanjutan, Sementara Arif Darmawan, M.A. menyampaikan materi tentang pariwisata berbasis komunitas dan Hadi Prayitno menyampaikan materi tentang pengelolaan sampah. Sebelum acara pelatihan berjalan, dilakukan tes awal (pre-test) dan setelah semua materi disampaikan di akhir pelatihan dilakukan tes akhir (post-test) untuk mengukur peningkatan pengetahuan perangkat desa dan BPD.

\section{Perencanaan}

Kegiatan pengabdian yang merupakan program yang direncanakan oleh dosen lintas fakultas Universitas Lampung, telah berjalan dengan baik dan sesuai dengan jadwal yang telah ditentukan. Dan juga tidak ditemukan kendala berarti dalam hal peserta, dana, dan tempat kegiatan.

Kegiatan pengabdian didahului dengan tim pengabdian melakukan survei atau pemetaan 
berkaitan dengan tempat dan peserta. Dari survei tersebut didapatkan gambaran kondisi, kemampuan serta dasar kelompok sasaran. Kemudian tim pengabdian membuat kesepakatan mengenai waktu dan tempat kegiatan pelatihan bagi aparat desa, sarana dan prasarana yang akan digunakan serta dana yang diperlukan selama kegiatan berlangsung.

Sebelum penyuluhan berlangsung, diadakan pre-test dan dialog dengan peserta untuk lebih meyakinkan tim pengabdian masyarakat terhadap gambaran, kemampuan serta pengetahuan dasar kelompok sasaran. Berdasarkan hasil dialog tersebut, sebagian besar kelompok sasaran belum memahami dengan baik tentang arti penting pariwisata berkelanjutan. Secara menyeluruh. Dengan demikian dapat dikatakan bahwa perlu adanya penguatan kelembagaan pemerintahan desa melalui pelatihan dan penyuluhan.

\section{Proses Pelaksanaan}

Seluruh peserta yang terlibat dalam kegiatan sangat antusias dan serius, mereka mengapresiasi dengan sangat baik. Para penyuluh memberikan materi dan arahan dengan baik, dibawakan dengan santai tapi serius. Sementara peserta mengikuti penyajian materi dengan seksama, sehingga pelaksanaan kegiatan berjalan lancar dan tidak ada waktu yang terbuang percuma. Selain itu peserta juga mengikuti tata tertib kegiatan yang disepakati bersama, mengikuti kegiatan dari awal sampai akhir. Para penyuluh juga membangun interaksi yang baik sehingga saat tanya jawab berlangsung, peserta tidak segan untuk mengajukan pertanyaan.

Materi yang diberikan dengan bahasa yang mudah dipahami peserta. Materi yang diberikan meliputi: pariwisata berkelanjutan, pemberdayaan pariwisata berbasis masyarakat dan budaya pengelolaan sampah.

\section{Pengetahuan terkait dengan Potensi Pantai Mutiara Baru}

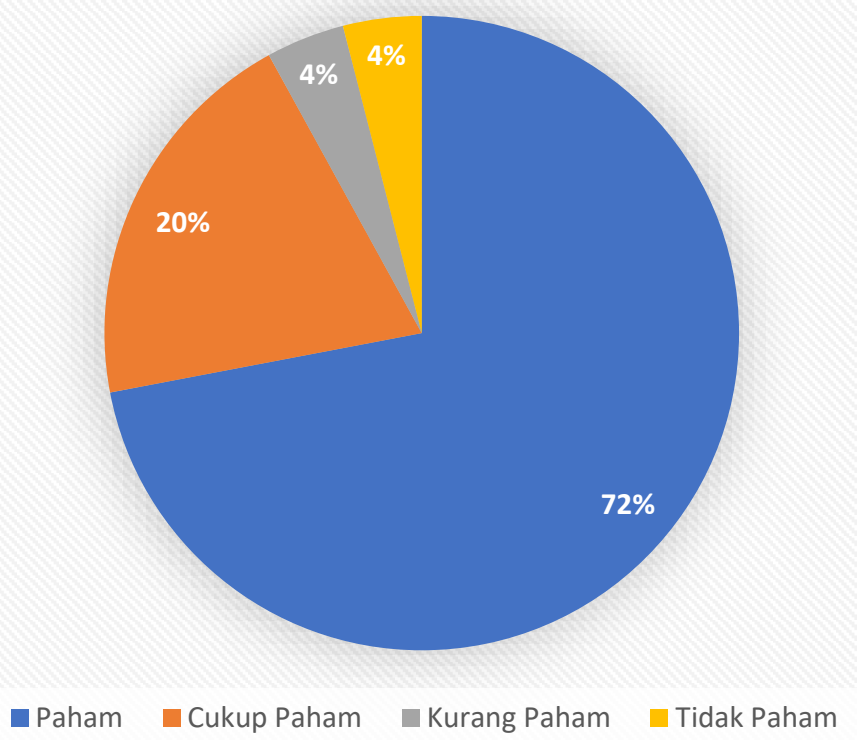

Gambar 1. Hasil Pre-Test Pemahaman Masyarakat terkait Pengembangan Wisata Pantai Mutiara Baru, Desa Karya Makmur, Labuhan Maringgai, Lampung Timur.

Dari grafik diatas menjelaskan bahwa pada saat dilaksanakan pre-test, pemahaman terkait potensi wisata Pantai Mutiara Baru mencapai $72 \%$ (16 orang paham akan potensi dari Pantai Mutiara Baru), sedangkan $20 \%$ (5 orang menyatakan cukup paham) dan sisanya (2 orang menyatakan tidak paham). 


\section{Pemahaman terkait Konsep Ekowisata}

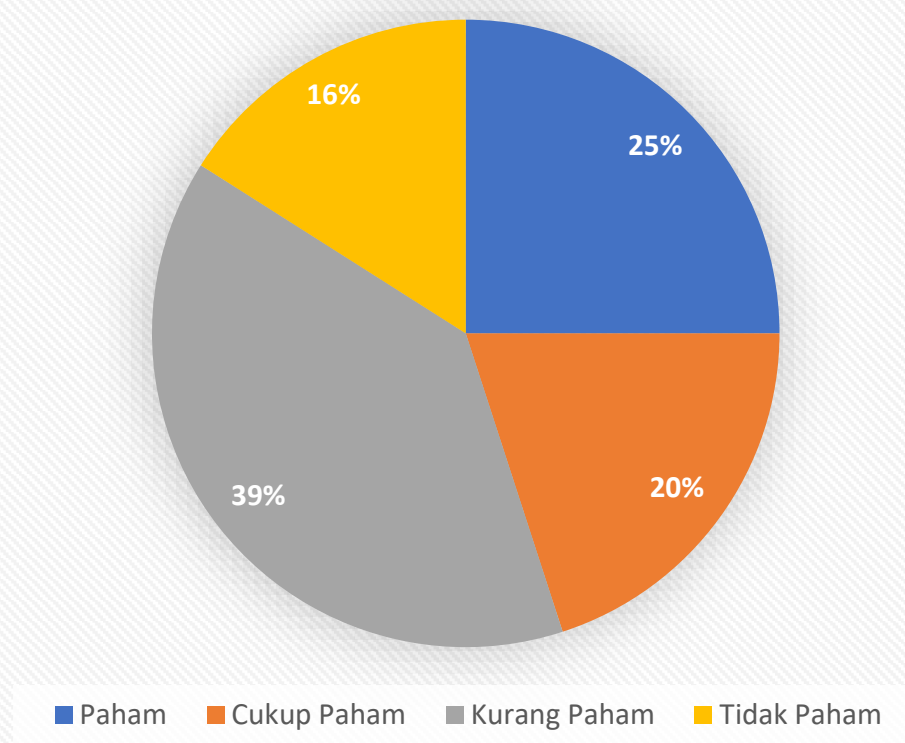

Gambar 2. Hasil Pre-Test Pemahaman Masyarakat terkait Konsep Ekowisata Pantai Mutiara Baru, Desa Karya Makmur, Labuhan Maringgai, Lampung Timur.

Dari grafik diatas menjelaskan bahwa pada saat dilaksanakan pre-test, pemahaman terkait konsep ekowisata Pantai Mutiara Baru hanya mencapai $25 \%$ (5 orang paham akan konsep ekowisata), sedangkan $20 \%$ (5 orang menyatakan cukup paham) dan sisanya 59\% (11 orang menyatakan kurang memahami terkait konsep ekowisata).

\section{Sektor yang paling penting untuk dibangun}

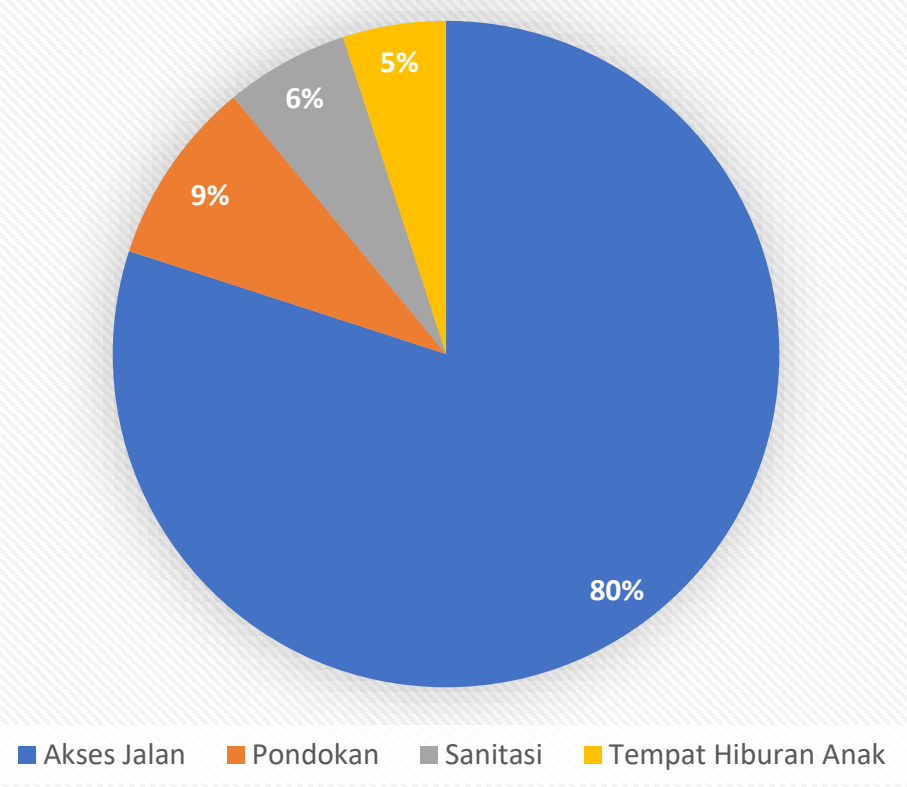

Gambar 3. Hasil Pre-Test Pemahaman Masyarakat terkait Sektor yang paling penting untuk dibangun di Pantai Mutiara Baru.

Dari grafik diatas menjelaskan bahwa pada saat dilaksanakan pre-test, ditanyakan opini mengenai sektor yang harus dibangun di Pantai Mutiara Baru, hampir seluruh masyarakat yang menjadi responden menyatakan bahwa akses jalan adalah paling penting untuk pengembangan wisata pantai Mutiara Baru. 


\section{Pemahaman terkait Konsep Ekowisata}

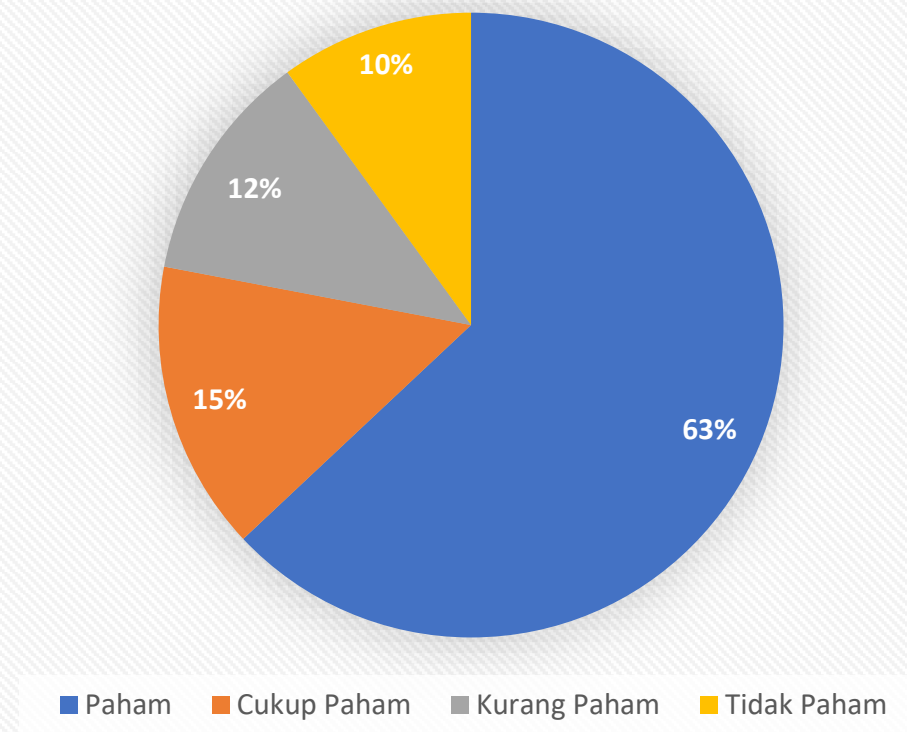

Gambar 4. Hasil Post-Test Pemahaman Masyarakat terkait Konsep Ekowisata Pantai Mutiara Baru, Desa Karya Makmur, Labuhan Maringgai, Lampung Timur.

Setelah diadakan post-test, tingkat pemahaman masyarakat terkait dengan konsep ekowisata meningkat menjadi $78 \%$ (16 orang menyatakan paham dan cukup paham dalam mengembangkan pantai mutiara baru berbasis ekowisata).

Desa Karya Makmur merupakan salah satu desa dari 21 desa yang ada di kecamatan Labuhan Maringgai, Kabupaten Lampung Selatan. Sepanjang jalan menuju ke sana dipenuhi tambak ikan dan udang. Saat diskusi berlangsung terungkap bahwa Karya Makmur yang pernah mengalami abrasi di sekitar tahun 1970-an. Di masa lalu garis pantai Mutiara Baru lebih menjorok $1 \mathrm{~km}$ ke arah laut, akan tetapi seiring dengan kerusakan lingkungan yang terjadi garis pantai terus terdesak ke arah daratan. Di pantai ini juga banyak ditemukan karang yang berukuran besar yang bisa diolah lebih lanjut untuk keperluan cinderamata atau bahan bangunan.

Berdasarkan hasil pengamatan dan perbandingan hasil pre-test dan post-test, ada perubahan pemahaman peserta dalam menyikapi konsep ekowisata. Dalam pelaksanan kegiatan ini ada beberapa faktor pendukung dan penghambat yang dihadapi.

\section{Faktor Pendukung}

Faktor pendukung kegiatan pengabdian masyarakat terhadap penguatan kelembagaan pemerintahan desa di Kecamatan Kalianda dapat dilaksanakan dengan baik karena didukung oleh:

- Apresiasi, kemauan, minat, dan perhatian yang cukup besar dari peserta dan tim baik sebelum dan sesudah penyuluhan.

- Rasa ingin tahu peserta sangat besar karena materi pengelolaan ini sedang hangat diperbincangkan, terutama setelah munculnya kesadaran masyarakat terhadap lingkungan

- Peserta bersedia meluangkan waktu sepenuhnya, karena keingintahuan mengenai materi pengelolaan sampah dan pariwisata berbasis komunitas.

- Penyediaan sarana dan prasarana dari pihak pemerintahan desa yang cukup memadai untuk melaksanakan pelatihan.

- Adanya dukungan dari LPPM Universitas Lampung. 


\section{Faktor Penghambat}

Tidak bisa dipungkiri, dalam pelaksanaan kegiatan ini ada kendala yang dihadapi, diantaranya:

- Peserta yang beragam latar belakang sehingga pemahaman juga kurang merata.

- Terbatasnya waktu dan dana yang tersedia sehingga bimbingan yang berkelanjutan belum bisa diwujudkan.

Berdasarkan pelaksanaan pelatihan peningkatan kapasitas perangkat desa yang berlangsung pada hari Rabu, tanggal 12 Agustus 2020 di Aula Pantai Mutiara Baru, Desa Karya Makmur, Kecamatan Labuhan Maringgai, Kabupaten Lampung Timur ditemukan beberapa masukan untuk kiranya ditindaklanjuti oleh dosen dan/atau FISIP Unila, serta pihak kecamatan dan desa sebagai berikut:

1. Sehubungan dengan menggeliatnya pariwisata di wilayah Lampung diperlukan kegiatan penyeluhan tentang ekowisata bagi generasi muda dalam membantu pemerintah desa memberi pemahaman tentang pengelolaan sampah sebagai dampak dari kegiatan pariwisata.

2. Dalam rangka penguatan kapasitas kepala desa dan perangkat desa di lingkungan Kecamatan Labuhan Maringgai dalam hal pengelolaan sampah, utamanya pembuatan ekobrick dan vertikultur, alangkah baiknya bila mahasiswa dan dosen Unila pada kesempatan mendatang bisa memberikan bantuan berupa asistensi, bimbingan, dan penyuluhan terkait hal tersebut.

\section{KESIMPULAN DAN SARAN}

\section{Kesimpulan}

Kegiatan Pengabdian ini telah mencapai tujuan yaitu:

1) Menigkatkan pemahaman serta kemamuan masyarakat Karya Makmur tentang pengolahan dan pemilihan sampah dengan prinsip 7R,

2) Mampu menciptakan lingkungan near waste zero untuk mendukung pembangunan berkelanjutan

3) Menjadikan Pantai Mutiara Baru objek wisata percontohan yang menarik wisatawan untuk berkunjung.

Hal ini dapat dilihat dari hasil pre-test dan post-test peserta sebelum dan setelah dilakukan pelatihan. Hasil penilaian quisioner dan wawancara tak terstruktur dengan para peserta juga menunjukkan bahwa sebagian besar peserta mampu memahami konsep Pengelolaan Sampah dengan Prinsip 7R yang menghasilkan produk ecobrick, hidroponik dan vertikulur. Dengan demikian, dapat dikatakan bahwa peserta merasakan manfaat setelah berpartisipasi dalam kegiatan pelatihan ini.

\section{Saran}

1. Perlu adanya pelatihan dan penyuluhan yang berkelanjutan untuk memberikan pengetahuan dan motivasi tentang potensi ecotourism kelompok sadar wisata kepada seluruh generasi muda,terutama dalam melakukan pengelolaan sampah sehingga dapat melestarikan lingkungan.

2. Perlu adanya alokasi penganggaran dalam Anggaran Pendapatan dan Belanja Desa untuk kegiatan pembinaan generasi muda sehingga bisa dilaksanakan secara rutin dan terus menerus yang dibiayai oleh pemerintah desa sendiri. 


\section{UCAPAN TERIMA KASIH}

Pengabdian kepada Masyarakat ini didanai oleh Universitas Lampung melalui Hibah Pengabdian kepada Masyarakat Skema Unggulan Tahun 2020 berdasarkan SK Rektor Universitas Lampung No. Tahun 2020. Oleh karena itu, penulis ingin mengucapkan terima kasih kepada Universitas Lampung, Anggota Pokdarwis Mutiara Baru dan Masyarakat Desa Karya Makmur.

\section{DAFTAR PUSTAKA}

[1] Fuldauer, L. dkk. 2019. Participatory planning of the future of waste management in small island developing states to deliver on the Sustainable Development Goals. Journal of Cleaner Production 223 (2019) $147-162$.

[2] Alqattan, Nael. Dkk. 2018. Reviewing the potential of Waste-to-Energy (WTE) technologies for Sustainable Development Goal (SDG) numbers seven and eleven. Renewable Energy Focus. Volume 27, Number 00. December 2018.

[3] Omer, M. dan Noguchi, T. 2019. A conceptual framework for understanding the contribution of building materials in the achievement of Sustainable Development Goals (SDGs). Sustainable Cities and Society. 